\title{
Isolation and Molecular Detection of Pathogenic Vibrio Species among Economic Fish from Red Sea in Egypt
}

\author{
Mohamed Wael Abdel-Azeem ${ }^{1}$, Ahmed Attaya ${ }^{1,2}$, Manal I. El-Barbary ${ }^{2}$ \\ and Serageldeen Sultan ${ }^{1^{\star}}$ \\ ${ }^{1}$ Department of Microbiology, Faculty of Veterinary Medicine, South Valley University, Qena 83523, \\ Egypt. \\ ${ }^{2}$ Fish Diseases Laboratory, Aquaculture Division, The National Institute of Oceanography and \\ Fisheries (NIOF), Red Sea Branch, Hurghada 84714, Egypt.
}

Authors' contributions

This work was carried out in collaboration between all authors. Authors SS, AA and MWAA designed the study, performed the statistical analysis and wrote the protocol. Author AA wrote the first draft of the manuscript and managed literature searches under supervision of author SS. Authors MWAA, AA, MIEB and SS managed the analyses of the study and literature searches. All authors read and approved the final manuscript.

Article Information

DOI: $10.9734 / \mathrm{BMRJ} / 2016 / 24016$ Editor(s):

(1) Lachhman Das Singla, Department of Veterinary Parasitology, College of Veterinary Science, Guru Angad Dev Veterinary and Animal Sciences University, India.

Reviewers:

(1) Pongsak Rattanachaikunsopon, Ubon Ratchathani University, Thailand.

(2) S. Thenmozhi, Periyar University, India.

Complete Peer review History: http://sciencedomain.org/review-history/13173

Original Research Article

Received $31^{\text {st }}$ December 2015

Accepted 23 $3^{\text {rd }}$ January 2016

Published $5^{\text {th }}$ February 2016

\section{ABSTRACT}

A total of 105 samples were collected from Siganus rivulatus, Mulloidichthys vanicolensis, and Lethrinus lentjan, freshly captured from the Red Sea along Hurghada City coastline zone, Egypt. Clinical and post mortem findings revealed the presence of characteristic clinical signs and lesions similar to those reported in vibriosis. Out of 43 putative Vibrio species isolates obtained by culturing; 30 isolates were presumptively discriminated into Vibrio cholera $(n=11)$, Vibrio anguillarum $(n=8)$, Vibrio fluvialis/ Vibrio furnissii $(n=4)$, Vibrio harveyi (Vibrio carchariae) $(n=4)$ and Vibrio alginolyticus $(\mathrm{n}=3)$, but it was not initially possible to approve or repudiate that the remaining 13 isolates were Vibrio species through phenotypic characterization. By using PCR, targeting 
Vibrio-specific 16S rRNA gene, the presumptive 30 Vibrio isolates and 9 out of the remaining 13 isolates were confirmed as Vibrio species. The prevalence of Vibrio species was $37.1 \%$ among the examined fish species; $47.1 \%, 34.3 \%$ and $30.6 \%$ in Mulloidichthys vanicolensis, Lethrinus lentjan and Siganus rivulatus, respectively. The occurrence of Vibrio species pathogenic for aquatic animals and humans was confirmed which possess public health concerns. Also, the utility of molecular technique to improve the identification of phenotypic Vibrio like species is recommended.

Keywords: Vibrio species; fish; phenotypic characterization; PCR; 16S rRNA gene; Egypt.

\section{INTRODUCTION}

Bacterial diseases outbreaks are a critical obstacle challenging aquaculture sector improvement worldwide [1,2]. The aquatic environment is a habitat for many bacterial pathogens, obligatory and opportunistic pathogens. Stresses exerted on fish due to the poor environmental conditions make them immunocompromised and, subsequently, more susceptible to pathogens infection $[2,3]$.

Vibrio species are a normal part of the bacterial flora in aquatic environments and some species are commonplace in/on aquatic animals; considered to be mostly opportunistic pathogens $[4,5]$. Several Vibrio species; Vibrio anguillarum and Vibrio tapetis, associated with diseases of aquatic animals, whereas other species including Vibrio cholerae, comprise serious pathogens of human. A comparatively small number of Vibrio parahaemolyticus and Vibrio vulnificus, causes disease in both aquatic animals and human $[5,6]$.

Vibrio species are responsible for vibriosis, one of the most devastating bacterial diseases in cultured fish and other aquatic animals globally $[6,7]$. The main pathogenic Vibrio species for marine fish are Vibrio alginolyticus, Vibrio anguillarum, Vibrio carchariae, Vibrio cholerae, Vibrio ordalii, Vibrio vulnificus and Vibrio parahaemolyticus, whereas, Vibrio mimicus and Vibrio cholerae are the main pathogenic Vibrio species for fresh water fish $[8,9]$.

Vibrio cholerae, Vibrio parahaemolyticus, Vibrio vulnificus, Vibrio alginolyticus, Vibrio mimicus, Vibrio fluvialis, Vibrio furnissii, Vibrio metschnikovii, Vibrio hollisae and Vibrio damselae are also pathogenic for humans, causing infections such as gastroenteritis, septicemia, wound and ear infections $[10,11]$.

The $0 / 129$ vibriostatic test is a useful as a primary screen for identification and differentiation of members of Vibrio species $[12,13]$.
Hurghada coastline is exposed to a variety of stresses as a result of anthropogenic activities, sewage pollution, hypersaline water rejection of desalination plants, shipping operations, and landfilling [14]. Stressed aquatic animals are more susceptible to microbial infections [1-3]. Vibriosis in fish is accompanied with stress but some strains, especially of Vibrio anguillarum, Vibrio ordalii and Vibrio salmonicida appear to be highly infectious primary pathogens. Several pathogenic Vibrio species outbreaks are known to be commonly associated with water contaminated with human feces or sewage $[15,16]$. Vibrios are typically more common in geographic regions having temperate or tropical climates [17]. Salinity, specifically sodium salt $\left(\mathrm{Na}^{+}\right.$, is the most important factor governing the environmental distribution of vibrios [18].

The prevalence of bacterial pathogens has been confirmed in several cultured and wild freshwater fish species, however; only a few bacteriological surveys have involved the marine species disease outbreaks [19]. The present study is aimed to assess the prevalence Vibrio species, using molecular and conventional methods, among three economic marine fish species captured from the Red Sea along Hurghada City coastline, Egypt.

\section{MATERIALS AND METHODS}

\subsection{Specimens and Clinical Findings of Captured Fish Species}

Over a 4 months period (May through August, 2012), a total of 105 samples from three different fish species (Fig. 1) were freshly captured in Hurghada city coastline zone, the Red Sea, Egypt by using small fishing vessels and gill nets. Whole fish were transported in ice-cooled insulated box to the laboratory within few hours, where they were investigated, Table 1 and Fig. 1. The clinical and post mortem (PM) examination were carried out according to the methods described by [13]. 
Table 1. Data of fish species captured and sampled in this study

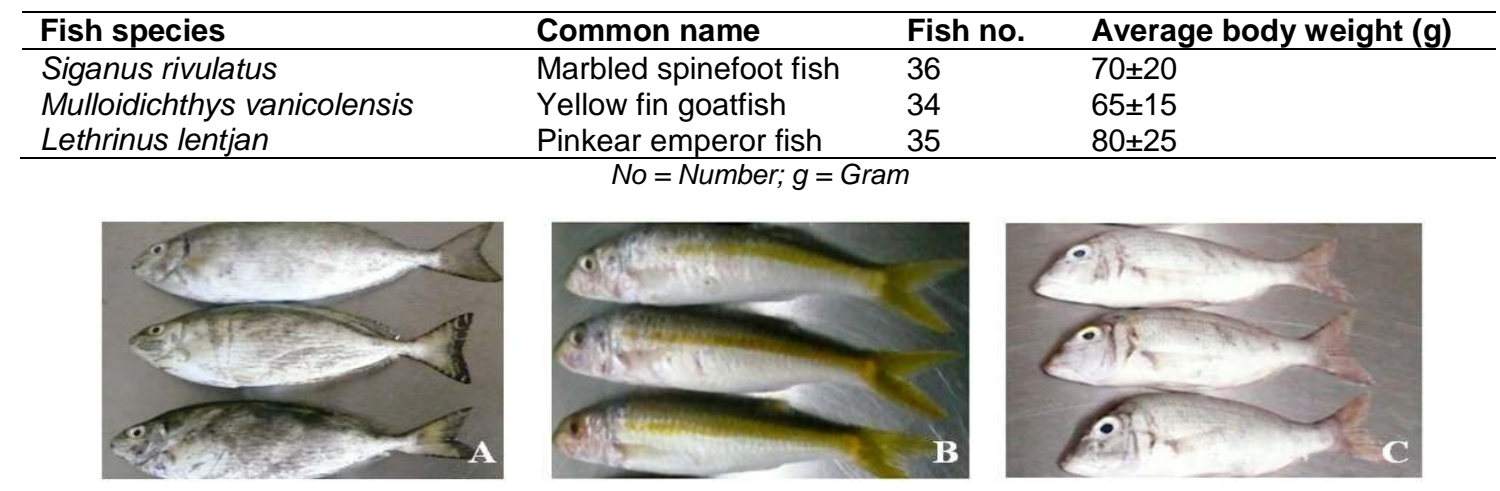

Fig. 1. Showing the morphological features of captured fish species in Hurghada City coastline zone, the Red Sea, Egypt

(A) Marbled spinefoot fish (Siganus rivulatus), (B) Yellowfin goatfish (Mulloidichthys vanicolensis) and (C) Pinkear emperor fish (Lethrinus lentjan)

\subsection{Isolation of Vibrio Species}

Fish liver, spleen and kidneys were sampled and cultured on general and selective media; tryptone soya agar (TSA, Oxoid) supplemented with $2 \%$ $(\mathrm{w} / \mathrm{v}) \mathrm{NaCl}$ and thiosulfate-citrate-bile saltssucrose agar (TCBS, Oxoid), the inoculated media were incubated in aerobic conditions at $3^{\circ} \mathrm{C}$ for $2-5$ days.

\subsection{Initial Phenotypic Screening for Putative Vibrio Species}

Pure cultures of putative Vibrio isolates were initially identified via analyzing phenotypic properties following the criteria described by $[12,13]$.

\subsection{Molecular Identification of Vibrio Species Using Polymerase Chain Reaction (PCR)}

Presumptive Vibrio species isolates were grown in tryptone soya broth (TSB, Oxoid) supplemented with $2 \%(\mathrm{w} / \mathrm{v}) \mathrm{Na} \mathrm{Cl}$ and incubated at $30^{\circ} \mathrm{C}$ for $18-24 \mathrm{~h}$. The broth cultures were then transferred into $1.5 \mathrm{ml}$ Eppendorf tubes and centrifuged at $5000 \mathrm{xg}$ at room temperature. The resulting pellet was used for nucleic acid extraction.

\subsubsection{DNA extraction from pure culture}

The DNA was extracted using the QIAamp ${ }^{\circledR}$ DNA Mini Kit (Qiagen, CA, USA) according to manufacturer's instructions. Briefly, the culture pellet was re-suspended in ATL buffer. Then, cell lysis was performed by proteinase $\mathrm{K}$ and incubation in a shacking water bath at $56^{\circ} \mathrm{C} / 60$ -
90 min. Then, AL buffer was added and incubated for a further $10 \mathrm{~min}$ at $70^{\circ} \mathrm{C}$. The DNA precipitation was performed by ethanol (96\%). The purified DNA was eluted by AE buffer. DNA concentration and purity were measured by spectrophotometer.

\subsubsection{PCR amplification of 162 bp of the Vibrio-specific 16S rRNA gene}

The eluted DNA was used as a template for PCR detection of Vibrio-specific 16S rRNA gene using two primers targeting $162 \mathrm{bp}$; forward primer 5'GTCAAAGCGATGCAGGTG-3' and reverse primer 5'-CTTCGCCACCGGTATTCCTT-3' [20].

PCR amplification was performed according to manufacturer's instructions. A total $25 \mu$ volume contains $12.5 \mu \mathrm{l}$ of HotStarTaq Master Mix (Qiagen, CA, USA), $1.5 \mu \mathrm{l}$ of $10 \mu \mathrm{M}$ of each primer and $3 \mu \mathrm{l}$ of DNA template. The mixture was processed in a gradient thermal cycler (LongGene, A200, Japan) with the following condition; $95^{\circ} \mathrm{C} / 15 \mathrm{~min}$ as an initial activation step for HotStarTaq DNA polymerase. To minimize PCR products derived from mis-priming events, the actual amplification was initiated with a "touchdown" PCR step consisting of 19 cycles at $94^{\circ} \mathrm{C} / 30 \mathrm{sec}, 60-51^{\circ} \mathrm{C} / 30$ sec (decreasing $0.5^{\circ} \mathrm{C} /$ cycle) and $72{ }^{\circ} \mathrm{C} / 1 \mathrm{~min}$ followed by 11 cycles of $94^{\circ} \mathrm{C} / 30 \mathrm{sec}, 51^{\circ} \mathrm{C} / 30 \mathrm{sec}$ and $72^{\circ} \mathrm{C} / 1$ $\mathrm{min}$. The process was finished with a single cycle at $72^{\circ} \mathrm{C} / 5 \mathrm{~min}$. The template-free reactions were included in the PCR setup as negative controls.

\subsubsection{PCR product visualization}

The amplified products were analyzed by electrophoresis on a 1.5\% agarose gel in 1× TAE 
buffer at $100 \mathrm{~V}$ for $45 \mathrm{~min}$ and visualized by ethidium bromide staining and a UV transilluminator (ECX-F20. M, France) and photographed by MicroDoc (Cleaver Scientific, UK). A 100-bp DNA Ladder (Promega, G210A, USA), consisting of DNA fragments ranging in size from 1500 to $100 \mathrm{bp}$, was used as a molecular weight marker.

\section{RESULTS AND DISCUSSION}

Fish were captured during May through August, 2012. Fish diseases including vibriosis outbreaks are more prevalent in spring and summer, high temperature is a major predisposing risk factor for most types of vibriosis, making it a summer disease in most, but not all cases [16].

Fish liver, spleen and kidneys are iron-rich filtering organs that make them predilection sites for Vibrio species localization [16,21,22].

The clinical examination of fish samples, revealed the presence of some clinical signs similar to those reported by [19] for vibriosis including, skin darkness and scales detachment, ulcers, small and large areas of hemorrhages distributed over many parts of the body, particularly at fins bases, mouth region, and abdomen area which varied in its severity from fish to another. The clinical signs were well marked in Mulloidichthys vanicolensis, mild in Siganus rivulatus and no clinical signs were observed in Lethrinus lentjan. Haemorrhages were most common in Mulloidichthys vanicolensis while only few Siganus rivulatus samples showed small areas of haemorrhages distributed over some parts of the bodies.

The PM examination of fish species, revealed the presence of lesions characteristic to vibriosis; varied degrees of congestion, enlargement of internal organs especially liver, spleen and kidneys, distention of gall bladder, congestion of intestines, and accumulation of body fluids in the abdominal cavity similar to those reported by $[23,24]$. The severity of PM lesions was in accordance with the clinical signs.

A total of 43 putative Vibrio isolates were obtained from TCBS agar [25]. The phenotypic properties analyzing of 30 putative Vibrio species isolates came in accordance with [12,13]. The 30 isolates (Siganus rivulatus (10), Mulloidichthys vanicolensis (12) and Lethrinus lentjan (8) were discriminated phenotypically into five presumptive Vibrio species including, Vibrio cholera $(n=11)$, Vibrio anguillarum $(n=8)$, Vibrio fluvialis/ Vibrio furnissii $(\mathrm{n}=4)$, Vibrio harveyi (V. carchariae) $(n=4)$ and Vibrio alginolyticus $(n=3)$, as outlined in Table 2 . The remaining 13 isolates (Siganus rivulatus (3), Lethrinus lentjan (6) and Mulloidichthys vanicolensis (4) were proved to be Gram-negative rods, motile, oxidase positive and have requirements for sodium chloride but were resistant to vibriostatic $0 / 129$ agent at both concentrations $(10$ and $150 \mu \mathrm{g}$ ). Hence, it wasn't initially possible to repudiate that the 13 isolates are Vibrio species through phenotypic properties analyzing (Table 3).

As shown in Fig. 2 and Table 3 when the 43 isolates were submitted for molecular identification using PCR via targeting Vibriospecific 16S rRNA gene, the 30 vibriostatic $0 / 129$ agent sensitive isolates were found positive for 16S rRNA gene. As well, 9 out of the 13 vibriostatic $0 / 129$ agent resistant isolates were found positive (Siganus rivulatus (1/3), Lethrinus lentjan (4/6) and Mulloidichthys vanicolensis (4/4) while the remaining 4 isolates were negative,. Subsequently, TCBS medium is associated with limitations and is not $100 \%$ selective for the isolation of Vibrio species where bacteria other than Vibrio such as Enterobacteriaceae could be grow on it $[26,27]$.

Vibriostatic $0 / 129$ agent sensitivity test is of a great value in differentiating some Vibrio species from other Gram-negative rods and particularly from aeromonads, which are characteristically resistant to vibriostatic $0 / 129$ agent. The degree of sensitivity of vibrios to $0 / 129$ agent can also be used as a diagnostic feature in differentiation of Vibrio species; Vibrio anguillarum is sensitive to 0/129 agent at both concentrations while Vibrio fluvialis is sensitive to $0 / 129$ agent at $150 \mu \mathrm{g}$ and resistant at $10 \mu \mathrm{g}[12,13]$. It is important to emphasis that negative $0 / 129$ agent test must be interpreted with caution; 9 vibriostatic $0 / 129$ agent resistant isolates were identified as Vibrio species using PCR.

The identity of putative Vibrio species isolates obtained from TCBS medium should therefore be confirmed employing a number of phenotypic and genetic techniques to accurately identify the atypical isolates [16,28,29]. PCR technique was definitely able to confirm 30 phenotypically presumptive Vibrio species and to assert the suspicions related to 13 vibriostatic 0/129 agent resistant isolates.

No Vibrio species were isolated from some Mullidicthes vanicolensis and Siganus rivulatus 
samples in spite of observing clinical signs, and vice versa. Consequently, the clinical signs might be due to Vibrio species infection and/or other etiological agents.

Table 2. Phenotypic profiles of Vibrio species isolated from examined fish

\begin{tabular}{|c|c|c|c|c|c|}
\hline \multirow[t]{2}{*}{ Test } & \multicolumn{5}{|c|}{ Percentage of isolates positive in the corresponding test (\%) } \\
\hline & $\begin{array}{l}\text { V. cholerae } \\
(\mathrm{n}=11)\end{array}$ & $\begin{array}{l}\text { V. fluvialis/ } \\
\text { V. furnissii } \\
(\mathrm{n}=4)\end{array}$ & $\begin{array}{l}\text { V. harveyi } \\
\text { (V. carchariae) } \\
(\mathrm{n}=4)\end{array}$ & $\begin{array}{l}\text { V. anguillarum } \\
(\mathrm{n}=8)\end{array}$ & $\begin{array}{l}\text { V. alginolyticus } \\
(\mathrm{n}=3)\end{array}$ \\
\hline TCBS & 100 & 100 & 100 & 100 & 100 \\
\hline $\mathrm{Gm}$ & 0 & 0 & 0 & 0 & 0 \\
\hline Mot & 100 & 100 & 100 & 100 & 100 \\
\hline Ox & 100 & 100 & 100 & 100 & 100 \\
\hline Cat & 100 & 100 & 100 & 100 & 100 \\
\hline Ind & 0 & 50 & 100 & 0 & 100 \\
\hline MR & 0 & 75 & 75 & 0 & 100 \\
\hline VP & 81.8 & 0 & 0 & 100 & 100 \\
\hline Cit & 72.2 & 75 & 100 & 100 & 100 \\
\hline ONPG & 100 & 100 & 100 & 100 & 0 \\
\hline LDC & 100 & 0 & 100 & 0 & 100 \\
\hline \multicolumn{6}{|c|}{$\mathrm{NaCl}$ requirement/ tolerance test: } \\
\hline $0 \% \mathrm{NaCl}$ & 100 & 0 & 0 & 12.5 & 0 \\
\hline $3 \% \mathrm{NaCl}$ & 100 & 100 & 100 & 100 & 100 \\
\hline $6 \% \mathrm{NaCl}$ & 18.2 & 100 & 100 & 100 & 100 \\
\hline $10 \% \mathrm{NaCl}$ & 0 & & 25 & 0 & 100 \\
\hline \multicolumn{6}{|c|}{ Vibriostatic agent (0/129) sensitivity test: } \\
\hline At $10 \mu \mathrm{q}$ & 100 & 0 & 0 & 100 & 0 \\
\hline At $150 \mu \mathrm{g}$ & 100 & 100 & 100 & 100 & 100 \\
\hline
\end{tabular}

Table 3. PCR-based identification of presumptive Vibrio species isolates and screening of vibriostatic 0/129 agent resistant isolates for Vibrio species

\begin{tabular}{|c|c|c|c|c|c|c|}
\hline \multirow[t]{3}{*}{ Fish species } & \multicolumn{3}{|c|}{ Presumptive Vibrio species isolates } & \multicolumn{3}{|c|}{$0 / 129$ agent resistant isolates } \\
\hline & \multirow{2}{*}{ No. of isolates } & \multicolumn{2}{|c|}{ Positive isolates } & \multirow{2}{*}{ No. of isolates } & \multicolumn{2}{|c|}{ Positive isolates } \\
\hline & & $\mathbf{N}$ & $\%$ & & $\mathbf{N}$ & $\%$ \\
\hline S. rivulatus & 10 & 10 & 100 & 3 & 1 & 33.3 \\
\hline M. vanicolensis & 12 & 12 & 100 & 4 & 4 & 100 \\
\hline L. lentjan & 8 & 8 & 100 & 6 & 4 & 66.7 \\
\hline Total & 30 & 30 & 100 & 13 & 9 & 69.2 \\
\hline
\end{tabular}

$N=$ number of isolates; \% =Percentage of isolates positive for Vibrio-specific 16S rRNA

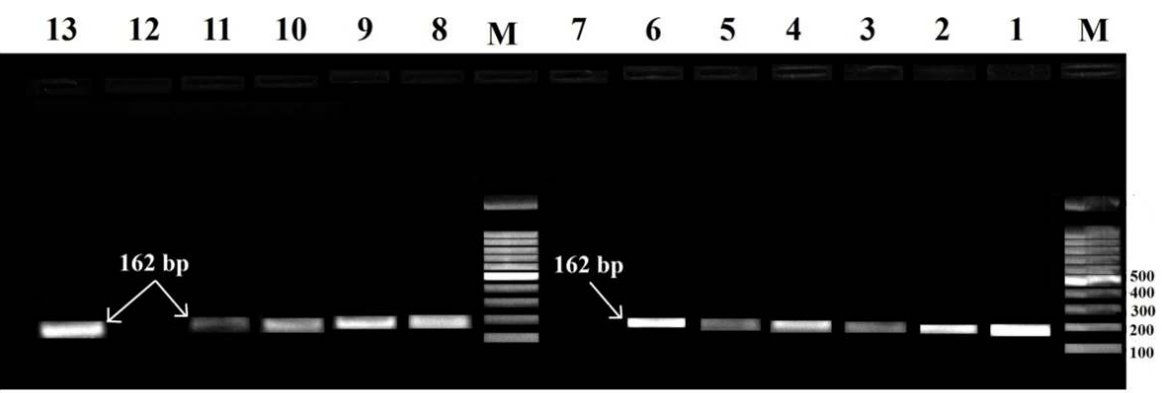

Fig. 2. The PCR product obtained using specific primers targeting $162 \mathrm{bp}$ of Vibrio spp $16 \mathrm{~S}$ rRNA gene after agarose gel electrophoresis and staining by ethidium bromide $(0.5 \mathrm{ug} / \mathrm{ml})$ and photographed by MicroDoc system using Canon digital camera

M= 100 bp DNA ladder; Lane 7: negative control (master mix without DNA); Lane 13: Positive control (V. anguillarum); Lanes: 1-6 and 8-11 Vibrio species positive samples; Lane 12: Vibrio species negative sample 
As outlined in Table 4, Vibrio species were detected in $37.1 \%$ of the total examined fish samples including, Vibrio cholerae (10.5\%), atypical Vibrio species (8.6\%), Vibrio anguillarum (7.6\%), $3.8 \%$ for each of Vibrio fluvialis/ Vibrio furnissii and Vibrio harveyi (Vibrio carchariae), and Vibrio alginolyticus (2.9\%). The prevalence of different Vibrio species varied among the examined fish species, Mulloidichthys vanicolensis showed the most prevalent Vibrio species $(47.1 \%)$ followed by Lethrinus lentjan $(34.3 \%)$ and Siganus rivulatus (30.6\%). Vibrio cholerae was the most predominant (28.2\%) among isolated Vibrio species. It was found that Vibrio cholera showed the highest isolation rate from Mulloidichthys vanicolensis (14.7\%) followed by Siganus rivulatus (13.9\%) and Lethrinus lentjan (2.9\%). The Vibrio anguillarum was detected in $14.7 \%, 8.6 \%$ and $0 \%$ of Mulloidichthys vanicolensis, Lethrinus lentjan and Siganus rivulatus, respectively. Vibrio alginolyticus was detected only in Lethrinus lentjan with a level of $8.6 \%$. Atypical Vibrio species were detected in $11.8 \%$ and $11.4 \%$ and $2.8 \%$ of Mulloidichthys vanicolensis, Lethrinus lentjan and Siganus rivulatus, respectively. The variations of Vibrio species occurrences and infection rates in the different fish species may be associated to various factors, including Vibrio species virulence, fish immunity, fish genetic factors, and physiological status, as well as the environmental stress conditions $[1,2,30]$.

The total prevalence of Vibrio species (37.1\%) in naturally infected marine fish species which appears to be higher than that reported by [31] which could be due to that most of the collected fish samples were freshwater fish while most Vibrio species are halophilic what decreases the viability and variability of Vibrio species in freshwater fish; this fact is very clear with comparison between Vibrio species incidences in Siganus rivulatus (50\%) and Oreochromis niloticus $(12.8 \%)$ in the same study. Also, they only sampled fish fleshes but in the present study liver, kidneys and spleen of examined fish were sampled $[16,21,22]$. The different fish species under both studies could give rise to variations in their susceptibility to Vibrio species infections. The high prevalence of Vibrio species may be attributed to the stresses induced by abundant anthropogenic activities in Hurghada City coastline zone in contrary to cultured fish farms which could be under good sanitary and management conditions. One of the most strong possible causes is that [31] depended in their study only on bacteriological analysis of examined fish and did not apply any molecular technique for screening their bacterial isolates for additional Vibrio species isolates while during the present study, applying of PCR technique added 9 Vibrio species isolates plus 30 initially phenotypically identified and PCR confirmed Vibrio species isolates.

The total prevalence of Vibrio species (37.1\%) appears to be lower than that reported by [32] who analyzed 150 samples from two types of freshwater fish (included, catfish "Pangasius hypophthalmus" and red tilapia "Oreochromis spp") commonly sold at hypermarkets in state of Selangor, Malaysia, for the presence of Vibriospecies applying PCR via targeting Vibriospecific 16S rRNA gene. Different fish species under both studies could give rise to variations in their susceptibility to Vibrio species also, they sampled the flesh and gills of fish which are in direct contact with aquatic environments bacteria

Table 4. Prevalence and distribution of Vibrio species among the examined fish

\begin{tabular}{|c|c|c|c|c|c|c|c|c|c|c|c|c|c|c|}
\hline Vibrio spp. & & 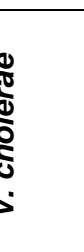 & & 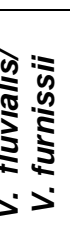 & & & & 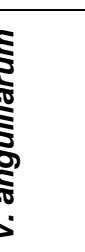 & 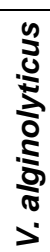 & & & & & \\
\hline & $\mathbf{N}$ & $\%$ & $\mathbf{N}$ & $\%$ & $\overline{\mathbf{N}}$ & $\%$ & $\mathbf{N}$ & $\%$ & $\mathbf{N}$ & $\%$ & $\mathbf{N}$ & $\%$ & $\mathbf{N}$ & $\%$ \\
\hline $\begin{array}{l}\text { S. rivulatus } \\
(\mathrm{n}=36)\end{array}$ & 5 & 13.9 & 1 & 2.8 & 4 & 11.1 & - & - & & - & 1 & 2.8 & 11 & 30.6 \\
\hline $\begin{array}{l}\text { M. vanicolensis } \\
(\mathrm{n}=34)\end{array}$ & 5 & 14.7 & 2 & 5.9 & - & - & 5 & 14.7 & - & - & 4 & 11.8 & 16 & 47.1 \\
\hline $\begin{array}{l}\text { L. lentjan } \\
(\mathrm{n}=35)\end{array}$ & 1 & 2.9 & 1 & 2.9 & - & - & 3 & 8.6 & 3 & 8.6 & 4 & 11.4 & 12 & 34.3 \\
\hline Total $=105$ & 11 & 10.5 & 4 & 3.8 & 4 & 3.8 & 8 & 7.6 & 3 & 2.9 & 9 & 8.6 & 39 & 37.1 \\
\hline
\end{tabular}


including, Vibrio species and sampled fish intestinal tracts where genus Vibrio dominates microbiota [33,34].

\section{CONCLUSION}

The pathogenic Vibrio species are prevalent among the examined economic fish in Red Sea, along Hurghada City coastline, Egypt which possess public health concerns, necessity need for applying hygienic measurements to avoid water contamination and spread of infection among aquatic animals and human. The usage of combination of molecular and conventional methods for Vibrio species identification is necessary.

\section{SIGNIFICANCE AND IMPACT OF THE STUDY}

Vibrio species are common inhabitants in/on the aquatic animals, some species are pathogenic for aquatic animals and others are pathogenic for humans, meanwhile other species are pathogenic for both aquatic animals and humans. So, this study identifies Vibrio species isolated from three economic fish species in the Red Sea, Egypt, and assesses their prevalence and distribution using the conventional and molecular methods. The pathogenic Vibrio species for aquatic animals and humans are prevalent among economic fish in Egypt which possess public health concerns. The usage of molecular and conventional methods, together, for Vibrio species identification is necessary.

\section{COMPETING INTERESTS}

Authors have declared that no competing interests exist.

\section{REFERENCES}

1. Verschuere L, Rombaut G, Sorgeloos P, Verstraete $W$. Probiotic bacteria as biological control agents in aquaculture. Microbiol Molecul Biol Rev. 2000;64:655671.

2. Schulze AD, Alabi AO, Sheldrake AR, Miller KM. Bacterial diversity in a marine hatchery: Balance between pathogenic and potentially probiotic bacterial strains. Aquaculture. 2006;256:50-73.

3. Hansen $\mathrm{GH}$, Olafsen JA. Bacterial interactions in early life stages of marine cold water fish. Microbial Ecol. 1999;38:1-26.
4. Gomez-Gil B, Thompson FL, Thompson C., Garcia-Gasca A, Roque A, Swings J. Vibrio hispanicus sp. nov., isolated from Artemia sp. and sea water in Spain. Int. J Sys Evol Microbiol. 2004;54(pt 1):261-265.

5. Farmer III JJ, Janda M, Brenner FW, Cameron DN, Birkhead KM. Genus I: Vibrio Pacini 1854, 411 ${ }^{\mathrm{AL}}$. In: Brenner, DJ, Krieg NR, Staley JT, (eds), Bergey's Manual of Systematic Bacteriology, $2^{\text {nd }}$ ed. Vol. 2, The Proteobacteria, Part B, The Gammaproteobacteria. New York, Springer-Verlag. 2005;494-546.

6. Austin B, Austin DA. Bacterial fish pathogens, disease of farmed and wild fish, 4th ed. Springer Praxis, Godalming; 2007.

7. Inglis V, Roberts RJ, Bromage NR. Bacterial diseases of fish. New York: Halsted Press; 1993.

8. Farkas J, Malik SE. Vibrio disease of Sheatfish (Silrus glanis L.) fry. Aquac. 1986;51:81-88.

9. Tison DL, Murray PR, Baron EJ, Pfaller MA, Tenover FC, Yolken $\mathrm{RH}$. Manual of Clinical Microbiology $7^{\text {th }}$ ed. Washington D.C. ASM. 1999;487.

10. Fouz B, Alcaide E, Barrera R, Amaro C. Susceptibility of Nile Tilapia (Oreochromis niloticus) to vibriosis due to Vibrio vulnificus bio type 2 (Serovar E). Aquaculture. 2002;212:21-30.

11. Finkelstein RA. Cholera, Vibrio cholera $\mathrm{O} 1$ and O139, and other pathogenic vibrios; 2000.

Available:http://gsbs.utmb.edu/microbook/c h024.htm

(Accessed $12^{\text {th }}$ January, 2007)

12. Holt JG, Krieg NR, Sneath PHA, Staley JT, Williams ST. Bergey's manual of determinative bacteriology. $9^{\text {th }}$ edn. Lippincott Williams \& Wilkins, New York; 2000.

13. Buller NB. Bacteria from fish and other aquatic animals: A practical Identification Manual. CABI Publishing, Cambridge; 2004.

14. Madkour HA, Dar MA. The anthropogenic effluents of the human activities on the Red Sea coast at Hurghada harbour (case study). Egy J Aqua Res. 2007;33:43-58.

15. Igbinosa EO, Okoh Al. Emerging Vibrio species: An unending threat to public health in developing countries. Res Microbiol. 2008;159:495-506. 
16. Noga EJ. Fish disease: Diagnosis and treatment. $2^{\text {nd }}$ ed. Wiley-Blackwell publication, USA; 2010.

17. Motes ML, DePaola A, Cook DW, Veazey JE, Hunsucker JC, Garthright WE, Blodgett RJ, Chirtel SJ. Influence of water temperature and salinity on Vibrio vulnificus in Northern Gulf and Atlantic Coast oysters (Crassostrea virginica). Appl Environ Microbiol. 1998;64:1459-1465.

18. Baumann P, Furniss AL, Lee JV. Genus I. Vibrio. In Krieg and Holt (Editors), Bergey's Manual of Systematic Bacteriology, $1^{\text {st }}$ ed., Vol. 1, The Williams \& Wilkins Co. Baltimore. 1984;518-538.

19. Toranzo AE, Magarinos B, Romaldo JL. A review of the main bacterial fish diseases in mariculture systems. Aquaculture. 2005;246:37-61.

20. Gonzalez-Escalona N, Fey A, Hofle MG, Espejo RT, Guzman CA. Quantitative reverse transcription polymerase chain reaction analysis of Vibrio cholerae cells entering the viable but non-culturable state and starvation in response to cold shock. Environ Microbiol. 2006;8(4):658-666.

21. Amaro C, Aznar R, Alcaide E, Lemos ML. Iron-binding compounds and related outer membrane proteins in Vibrio cholerae nonO1 strains from aquatic environments. Appl Environ Microbiol. 1990;56:24102416.

22. Guerinot ML. Microbial iron transport. Annu Rev Microbiol. 1994;48:743-772.

23. Xio CQ, Huang J, Liao JZ. Pathological and pathogenic study on vibriosis in eels. Chinese J of Vet Sci. 2005;19(3):258-260. Chinese.

24. Roaeder IL, Paulson SM, Willassen NP. Effect of fish skin mucous on the soluble protein of Vibrio salmonicida analysis by 2D gel electrophoresis. Microb Pathogen. 2007;42:36-45.

25. Pfeffer C, Oliver JD. A comparison of thiosulphate-citrate-bile salts-sucrose (TCBS) agar and thiosulphate-chlorideiodide (TCl) agar for the isolation of Vibrio species from estuarine environments. Lett Appl Microbiol. 2003;36:150-151.
26. Gomez-Gil B, Roque A. Isolation, enumeration and preservation of Vibrionaceae. In: Thompson FL, Austin B, Swings J, editors. The Biology of Vibrios. Washington DC: ASM Press; 2006.

27. Shikongo-Nambabi MNNN, Petrus NP, Schneider MB. The role, isolation and identification of Vibrio species on the quality and safety of seafood. Biotechnol Molecular Biol Rev. 2012a;7:16-30.

28. Brasher CW, DePaola A, Jones DD, Bej AK. Detection of microbial pathogens in shellfish with multiplex PCR. Curr. Microbiol. 1998;37:101-107.

29. Shikongo-Nambabi MNNN, Chimwamurombe PM, Venter SN. Identification of putative Vibrio species isolated from processed marine fish using Thiosulphate-Citrate-Bile-Sucrose (TCBS) agar. British Biotech J. 2012b;2(4):229246.

30. Bachère $E$, Mialhe $E$, Noël $D$, Boul V, Morvan A, Rodrigues J. Knowledge and research prospects in marine mollusc and crustacean immunology. Aquaculture. 1995;132:17-32.

31. Al-Sunaiher AE, Ibrahim ASS, Al-Salamah, AA. Association of Vibrio species with disease incidence in some cultured fishes in the Kingdom of Saudi Arabia. World Appl Sci J. 2010;8(5):653-660.

32. Noorlis A, Ghazali FM, Cheah YK, Tuan Zainazor TC, Ponniah J, Tunung R, Tang JYH, Nishibuchi M, Nakaguchi Y, Son R. Prevalence and quantification of Vibrio species and Vibrio parahaemolyticus in freshwater fish at hypermarket level. Int Food Res J. 2011;18:689-695.

33. Thompson FL, lida $\mathrm{T}$, Swings J. Biodiversity of Vibrios. Microbiol Molecular Biol Rev. 2004;68:403-431.

34. Reid HI, Treasure JW, Adam B, Birkbeck $\mathrm{TH}$. Analysis of bacterial populations in the gut of developing cod larvae and identification of Vibrio logei, Vibrio anguillarum and Vibrio splendidus as pathogens of cod larvae. Aquaculture 2009;288:36-43.

(C) 2016 Abdel-Azeem et al.; This is an Open Access article distributed under the terms of the Creative Commons Attribution License (http://creativecommons.org/licenses/by/4.0), which permits unrestricted use, distribution, and reproduction in any medium, provided the original work is properly cited.

Peer-review history:

The peer review history for this paper can be accessed here: http://sciencedomain.org/review-history/13173 